\title{
Differential incision of the Grand Canyon related to Quaternary faulting-Constraints from U-series and Ar/Ar dating
}

\author{
Joel Pederson Department of Geology, Utah State University, Logan, Utah 84322, USA \\ Karl Karlstrom Earth and Planetary Sciences, University of New Mexico, Albuquerque, New Mexico 87131, USA \\ Warren Sharp Berkeley Geochronology Center, Berkeley, California 94709, USA \\ William McIntosh New Mexico Institute of Mining and Geology, Socorro, New Mexico 87801, USA
}

\begin{abstract}
Incision of the Colorado River in the Grand Canyon, widely thought to have happened between ca. 6 and $1.2 \mathrm{Ma}$, has continued at variable rates along the canyon over the past $\sim 500 \mathrm{k} . y$., based on measurements of bedrock incision combined with U-series and ${ }^{40} \mathrm{Ar} /$ ${ }^{39} \mathrm{Ar}$ ages. River incision rates downstream of the Toroweap fault in the western Grand Canyon are about half the $\sim 140 \mathrm{~m} / \mathrm{m}$.y. incision rate calculated for a distance of at least $200 \mathrm{~km}$ upstream of the fault. We hypothesize that this differential incision is due to westdown slip on the Toroweap fault of $94 \pm 6 \mathrm{~m} / \mathrm{m} . \mathrm{y}$. based on measured offset of the newly dated Upper Prospect basalt flow, which is the major middle-late Quaternary slip evident along the river. Regional incision has been driven mostly by base-level fall related to drainage reversal off the Colorado Plateau ca. 6 Ma. Because local normal faulting is lower in rate than this regional incision and is likely an expression of Basin and Range extension and subsidence rather than uplift, this is a case where active faulting diminishes, but does not drive, incision. Quaternary incision rates are insufficient to have carved the Grand Canyon in $6 \mathrm{~m} . y$., suggesting either that rates have decreased through time as the original base-level signal has attenuated, or that some component of the canyon relief we see today existed prior to Colorado River integration.
\end{abstract}

Keywords: faulting, geochronology, geomorphology, Grand Canyon, incision.

\section{INTRODUCTION AND BACKGROUND}

There has been a lengthy debate over the causes and timing of the incision of the Grand Canyon, but this famous erosional feature is ultimately the product of a large-scale reversal in drainage direction that happened over the course of late Cenozoic time (e.g., Blackwelder, 1934; Longwell, 1946; Lucchitta, 1972). Early Cenozoic (Laramide) uplift of the ancestral Mogollon highlands to the south of the present-day Colorado Plateau created consequent and deeply incised drainages that flowed Canyon region and are still evident as paleocanyons and related deposits (Young and McKee, 1978; Potochnik and Faulds, 1998). These highlands collapsed during Basin and Range extension, which peaked in early to middle Miocene time along the southern and western margins of the plateau (e.g., Young and Brennan, 1974; Faulds et al., 1997). This topographic inversion from Laramide highlands to extensional basins along the edge of the plateau disrupted drainages and generated relief that, once drainages became integrated, reversed flow toward the opening Gulf of California (Lucchitta, 1972). This must have provided a $1000+\mathrm{m}$ drop in local base level, steepening streams and driving incision on the Colorado Plateau. The present-day Colorado River exits the plateau and enters the Basin and Range by crossing the Grand Wash fault and the adjacent Grand Wash trough (Fig. 1). to the north and northeast toward the Grand
The Grand Wash fault was active during middle Miocene extension, but there is no evidence of post-late Miocene offset (Lucchitta, 1966; Faulds et al., 2002). Analysis of the sedimentary and erosional record of the Grand Wash trough reveals a change from internalbasin deposition in latest Miocene time to subsequent incision by a throughgoing river, indicating that drainage integration across the Grand Wash escarpment was complete-and presumably incision of the Grand Canyon began-just after 6 Ma (Longwell, 1946; Lucchitta, 1966; Spencer et al., 2002).

It generally has been thought that most
Grand Canyon incision occurred between 6 and 1.2 Ma based upon K-Ar ages of basalts that flowed from the Uinkaret volcanic field into a paleo-Grand Canyon that was nearly as deep as the present canyon (Hamblin, 1994; Fig. 1). However, recent work on Quaternary stratigraphy and soils and new ${ }^{40} \mathrm{Ar} /{ }^{39} \mathrm{Ar}$ ages of basalt flows indicate significant river incision rates throughout the canyon and more rapid incision in the eastern Grand Canyon based on estimated ages of terrace treads (Machette and Rosholt, 1991; Lucchitta et al., 2000). In addition, Uinkaret basalts are younger than previously thought $(<600 \mathrm{ka}$; Dalrymple and Hamblin, 1998), and we now better understand the down-to-the-west slip along the Hurricane-Toroweap fault zone, which has overlapped temporally with river incision (Jackson, 1990; Stenner et al., 1999; Fenton et al., 2001). We present here new absolute ages on travertine and basalt flows in unusual field relations that provide high-quality incision rates for the past $\sim 500$ k.y. Our calculated rates are generally lower than previous estimates, but confirm that Quaternary incision has varied significantly along the length of the Grand Canyon. We then explore how this differential incision may be linked to Quaternary slip along the Hurricane-Toroweap fault zone.

\section{RIVER INCISION RATES}

The episodic stream aggradation and degradation that created the fill terraces of the

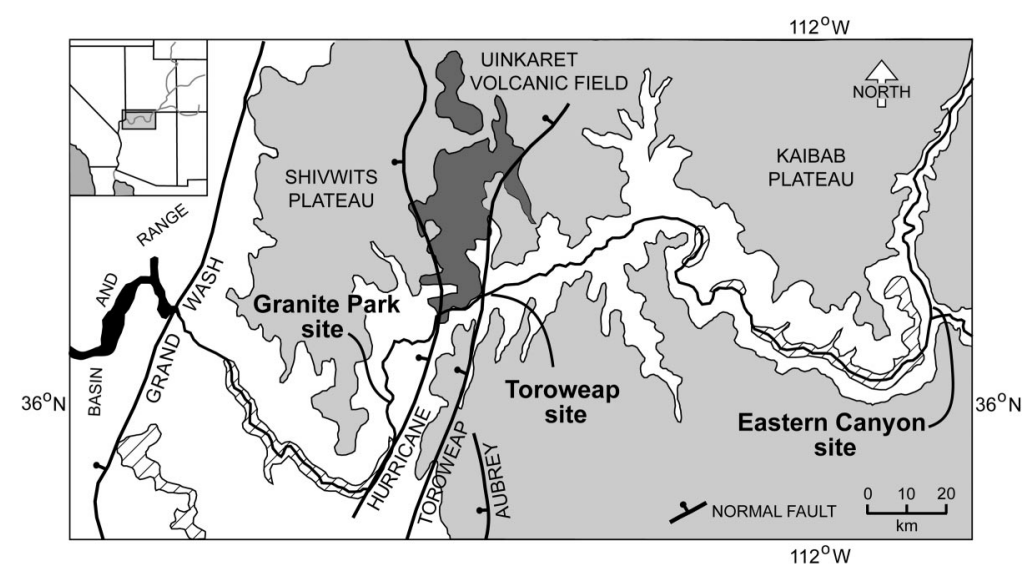

Figure 1. Map of Grand Canyon region showing major features and faults. Dark gray-Quaternary-Tertiary basalt of Uinkaret volcanic field; light grayPermian Kaibab Limestone; white-Cambrian to Permian bedrock; diagonal pattern-Precambrian bedrock. 


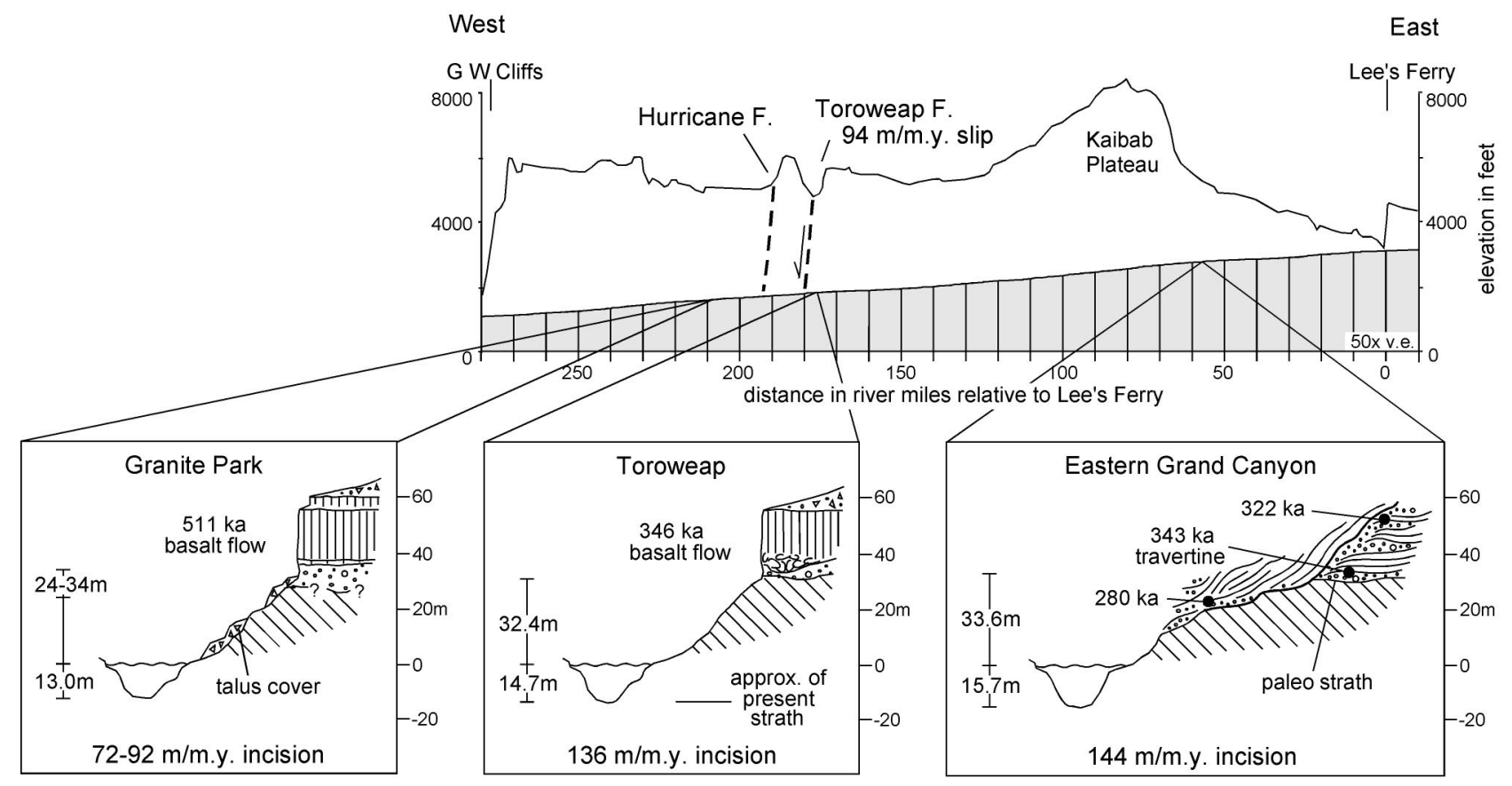

Figure 2. Longitudinal profile of Colorado River through Grand Canyon; data from Birdseye (1924), with smoothed topographic profile (from digital elevation model) of canyon's north rim, and depth-of-river data found in Wilson (1986). Inset schematic drawings show relations used to calculate incision rates at three localities. Bedrock incision rates in eastern Grand Canyon are greater than those west of Toroweap fault $\left(F_{.}\right)$.

Grand Canyon were superimposed on overall downcutting in middle to late Quaternary time. We have calculated long-term bedrock incision rates at two locations east and one location west of the Hurricane-Toroweap fault zone using radiometric ages on travertine and basalt within gravel fill just above the bedrock straths of terraces (Fig. 2). Our dates provide minimum ages for the bedrock strath and we calculate bedrock incision rates by adding the surveyed heights of the straths above a reference river stage to the mean pool depths of the adjacent $\sim 24 \mathrm{~km}$ reach of the present-day river (determined from the data of Wilson, 1986). Mean pool depth is the best estimate of depth to bedrock under the present river because channel depth along the river varies greatly from rapids to pools, and the river channel varies from alluvial to bedrock (Roberto Anima, U.S. Geological Survey, 2001, personal commun.). Pool depth thus provides a comparison of past bedrock straths to present bedrock levels. Our use of terrace straths and deposits with ages consistently on the order of $10^{5} \mathrm{yr}$ for incision-rate calculations al- lows us to avoid the effects of varying time interval on incision rates (Gardner et al., 1987; Mills, 2000). Uncertainties in the radiometric ages and incision rates, where appropriate, are given at the $95 \%$ confidence level. The latter includes both contributions from the ages and the mean pool depths that were combined quadratically.

\section{Eastern Grand Canyon}

We have dated three samples of travertine flowstone using the ${ }^{230} \mathrm{Th} / \mathrm{U}$ method (e.g., Edwards et al., 1987) on dense, milligram-size samples selected from polished slabs exhibiting primary textures (Table 1; Fig. 2). The dated travertines interfinger with gravelly alluvium, indicating a paleoenvironment where spring deposits were precipitating near the river's shoreline. Travertine $1(343 \pm 28 \mathrm{ka})$ is $2.2 \mathrm{~m}$ above the bedrock strath of a fill terrace and travertine $2(322 \pm 9.7 \mathrm{ka})$ is higher in this same fill (Fig. 2). Travertine $3(280 \pm 8.9$ $\mathrm{ka}$ ) is $0.5 \mathrm{~m}$ above the bedrock flank of a deposit that is inset into the deposit containing 1 and 2. Samples 1 and 3 provide minimum ages for when the paleoriver had incised to levels 33.6 and $22.0 \mathrm{~m}$, respectively, above the reference river stage. Combining these data with the reach-averaged pool depth of $15.7 \pm$ $4.5 \mathrm{~m}$ yields incision rates of $144 \pm 18$ and $135 \pm 17 \mathrm{~m} / \mathrm{m}$.y. The ${ }^{230} \mathrm{Th} / \mathrm{U}$ ages are consistent with stratigraphy and give consistent estimates for the long-term incision rate, indicating that they are reliable. Our incision rates in the eastern Grand Canyon are generally lower and more precise than estimates by previous workers, who reported that rates increase from 100 to $700 \mathrm{~m} / \mathrm{m}$.y. with progressively younger terraces (Machette and Rosholt, 1991). We consider our results more reliable because we avoid this bias of shorter time-interval measurements toward higher rates (Gardner et al., 1987), because some of the previous rates were based on the nowabandoned uranium-trend dating technique, and because we compare past bedrock surfaces to present bedrock levels.

\section{Toroweap and Granite Park Localities}

A basalt flow at river mile 177, located $\sim 2.5 \mathrm{~km}$ upstream of the Toroweap fault,

TABLE 1. URANIUM-SERIES DATA FOR TRAVERTINES OF EASTERN GRAND CANYON

\begin{tabular}{|c|c|c|c|c|c|c|c|c|c|c|}
\hline Sample & Location* & Stratigraphic position & $\begin{array}{l}\text { Weight } \\
\text { (mg) }\end{array}$ & $\begin{array}{l}{ }^{238} \mathrm{U} \\
\text { (ppm) }\end{array}$ & $\begin{array}{l}{ }^{232} \mathrm{Th} \\
(\mathrm{ppm})\end{array}$ & $\begin{array}{l}{ }^{230} \mathrm{Th} / \\
{ }^{232} \mathrm{Th}\end{array}$ & $\begin{array}{l}\text { Measured } \\
{ }^{230} \mathrm{Th} /{ }^{238} \mathrm{U}\end{array}$ & $\begin{array}{l}\text { Measured } \\
{ }^{234} \mathrm{U} /{ }^{238} \mathrm{U}\end{array}$ & $\begin{array}{l}\text { Age } \\
\text { (ka) }\end{array}$ & $\begin{array}{c}\text { Initial } \\
{ }^{234} \mathrm{U}^{238} \mathrm{U}^{\dagger}\end{array}$ \\
\hline GCTrav1 & $56.9 \mathrm{~L}$ & Near strath of fill terrace & 34.5 & 2.64 & 0.138 & 83.9 & $1.444 \pm 0.021$ & $1.380 \pm 0.0028$ & $343 \pm 28$ & $2.099 \pm 0.221$ \\
\hline GCTrav2 & $61.2 \mathrm{~L}$ & Higher within fill terrace & 30.9 & 1.77 & 0.045 & 206.0 & $1.706 \pm 0.009$ & $1.602 \pm 0.0048$ & $322 \pm 9.7$ & $2.507 \pm 0.037$ \\
\hline GCTrav3 & $57.0 \mathrm{~L}$ & Inset into fill terrace & 106.2 & 2.21 & 0.241 & 42.6 & $1.534 \pm 0.011$ & $1.507 \pm 0.0045$ & $280 \pm 8.9$ & $2.153 \pm 0.030$ \\
\hline
\end{tabular}


TABLE 2. AGE DETERMINATIONS FOR GRAND CANYON BASALTS

\begin{tabular}{|c|c|c|c|c|c|}
\hline Flow name & Location* & Method & $\mathrm{n}$ & Age (ka) & Reference \\
\hline Upper Gray Ledge & $188.4 \mathrm{R}$ & ${ }^{40} \mathrm{Ar} /{ }^{39} \mathrm{Ar} \mathrm{FSH}{ }^{\dagger}$ & 1 & $97 \pm 32$ & This study§,\# \\
\hline Lower Gray Ledge & $187.7 \mathrm{~L}$ & ${ }^{40} \mathrm{Ar} /{ }^{39} \mathrm{Ar} \mathrm{FSH}$ & 1 & $193 \pm 46$ & This study \\
\hline \multirow[t]{2}{*}{ Massive Diabase } & $194.8 \mathrm{R}$ & ${ }^{40} \mathrm{Ar} /{ }^{39} \mathrm{Ar} \mathrm{FSH}$ & 1 & $296 \pm 57$ & This study \\
\hline & & $\mathrm{K}-\mathrm{Ar}$ & 2 & $443 \pm 82$ & Dalrymple and Hamblin, 1998 \\
\hline \multirow[t]{2}{*}{ Whitmore Canyon } & & ${ }^{3} \mathrm{He}$ & 2 & $177 \pm 36$ & Fenton et al., 2001 \\
\hline & $189.6 \mathrm{R}$ & ${ }^{40} \mathrm{Ar} /{ }^{39} \mathrm{Ar} \mathrm{FSH}$ & 1 & $315 \pm 81$ & This study \\
\hline Mile 177 flow & $177.4 \mathrm{~L}$ & ${ }^{40} \mathrm{Ar} /{ }^{39} \mathrm{Ar} \mathrm{FSH}$ & 1 & $346 \pm 33$ & This study \\
\hline \multirow[t]{8}{*}{ Upper Prospect } & & ${ }^{3} \mathrm{He}$ & 1 & $395 \pm 70$ & Fenton et al., 2001 \\
\hline & & $\mathrm{K}-\mathrm{Ar}$ & 1 & $500 \pm 94$ & Dalrymple and Hamblin, 1998 \\
\hline & $179.4 \mathrm{~L}$ & ${ }^{40} \mathrm{Ar} /{ }^{39} \mathrm{Ar} \mathrm{FSH}$ & 1 & $483 \pm 22$ & This study \\
\hline & $179.4 \mathrm{~L}$ & ${ }^{40} \mathrm{Ar} /{ }^{39} \mathrm{Ar} \mathrm{FSH}$ & 1 & $526 \pm 30$ & This study \\
\hline & $179.4 \mathrm{~L}$ & ${ }^{40} \mathrm{Ar} /{ }^{39} \mathrm{Ar} \mathrm{FSH}$ & 1 & $528 \pm 83$ & This study \\
\hline & $179.4 \mathrm{~L}$ & ${ }^{40} \mathrm{Ar} /{ }^{39} \mathrm{Ar} \mathrm{FSH}$ & 1 & $529 \pm 29$ & This study \\
\hline & $179.4 \mathrm{~L}$ & ${ }^{40} \mathrm{Ar} /{ }^{39} \mathrm{Ar} \mathrm{FSH}$ & 1 & $534 \pm 56$ & This study \\
\hline & & ${ }^{40} \mathrm{Ar} /{ }^{39} \mathrm{Ar} \mathrm{FSH}$ (mean) & 5 & $509 \pm 27$ & This study \\
\hline \multirow[t]{2}{*}{ Black Ledge (G. Park) } & & ${ }^{40} \mathrm{Ar} /{ }^{39} \mathrm{Ar} \mathrm{FSH}$ (mean) & 9 & $603 \pm 16$ & Lucchitta et al., 2000 \\
\hline & $208.2 \mathrm{R}$ & ${ }^{40} \mathrm{Ar} /{ }^{39} \mathrm{Ar} \mathrm{FSH}$ & 1 & $511 \pm 63$ & This study \\
\hline
\end{tabular}

\footnotetext{
*Measured in river miles downstream of Lee's Ferry, "L" or "R" means left or right bank of river as facing downstream.

${ }^{\dagger} \mathrm{FSH}=$ furnace step heating.

$\S$ Spectra for new ages are generally flat, although some high- and low-temperature steps have elevated ages attributed to minor amounts of extraneous ${ }^{40} \mathrm{Ar}$.

\#Complete analytical data and age spectra are available from GSA Data Repository (see text footnote 1).
}

overlies mainstem sand and gravel and has pillow structures at its base, indicating that it flowed into the active riverbed (Fig. 2). This flow yields a ${ }^{40} \mathrm{Ar} /{ }^{39} \mathrm{Ar}$ plateau age of $346 \pm$ $33 \mathrm{ka}$ (Table 2; Table DR1 ${ }^{1}$ ). The base of this flow is $31.2 \mathrm{~m}$ above the reference river stage and the mean pool depth in this reach is 14.7 $\pm 3.3 \mathrm{~m}$, resulting in a bedrock incision rate of $133 \pm 16 \mathrm{~m} / \mathrm{m} . \mathrm{y}$. , which is indistinguishable from the rates we calculate for the eastern Grand Canyon locality.

Our incision-rate estimate from the Granite Park locality west of the Hurricane-Toroweap fault zone is, in contrast, significantly less. A $511 \pm 63$ ka basalt flow overlies mainstem river gravel $36.7 \mathrm{~m}$ above reference stage at this site, but the underlying bedrock strath, for which this basalt flow gives a minimum age, is obscured by talus at $24-34 \mathrm{~m}$ above reference, resulting in an estimated range of maximum incision rates of 72-92 m/m.y. (Fig. 2; Table 2). Lucchitta et al. (2002) calculated an incision rate of $\sim 70 \mathrm{~m} / \mathrm{m}$.y. when using comparable stratigraphic features and independent dates of the basalt flows at Granite Park.

\section{QUATERNARY FAULTING}

The Hurricane-Toroweap fault system is a 15 -km-wide zone of normal faults that forms the western edge of the neotectonic Colorado Plateau and is related to a wider zone of Basin and Range extension (Brumbaugh, 1987; Wong and Humphreys, 1989). The Uinkaret volcanic field is centered between these faults;

${ }^{1}$ GSA Data Repository item 2002085, Ar/Ar analytical data and age spectra, is available on request from Documents Secretary, GSA, P.O. Box 9140, Boulder, CO 80301-9140, USA, editing@geosociety. org, or at www.geosociety.org/pubs/ft2002.htm. numerous vents are aligned along their trend. Offset of basalt flows provides Quaternary slip rates along these faults. Neotectonic work on segments of the Hurricane and Toroweap faults near the Grand Canyon, along with ages mostly provided by cosmogenic ${ }^{3} \mathrm{He}$ surface exposure dates of basalt flows, alluvium, debrisflow deposits, and cinder-cone surfaces, led Fenton et al. (2001) to estimate down-to-thewest Quaternary slip rates of 70-180 m/m.y. for the Toroweap fault and $70-170 \mathrm{~m} / \mathrm{m}$.y. for the Hurricane fault.

Our new date of $509 \pm 27$ ka (weighted mean of five samples) on the Upper Prospect basalt flow of Hamblin (1994), which is offset $48 \mathrm{~m}$ by the Toroweap fault, gives a more precise slip rate of $94 \pm 6 \mathrm{~m} / \mathrm{m}$.y. (Fig. 2; Table 2). Plateau ages calculated from these age spectra are more precise than ${ }^{40} \mathrm{Ar} /{ }^{39} \mathrm{Ar}$ ages produced in the same laboratory and reported in Fenton et al. (2001), probably in large part because we sampled holocrystalline flow interiors. Samples near flow exteriors with interstitial glass can have reduced precision and accuracy because of atmospheric argon, susceptibility to ${ }^{39} \mathrm{Ar}$ recoil artifacts, and loss of radiogenic ${ }^{40} \mathrm{Ar}$. The ${ }^{3} \mathrm{He}$ cosmogenic exposure ages for the basalt flows reported in Fenton et al. (2001) are younger than our eruption ages, perhaps because progressive erosion of the flow surface removed part of the ${ }^{3} \mathrm{He}$ inventory. However, the slip rate we calculate is within the range they provided for the Toroweap fault.

It is established that the Hurricane fault north of the Colorado River has late Quaternary slip. However, like previous researchers (Hamblin, 1994; Wenrich et al., 1997), we have been unable to identify any offset of the

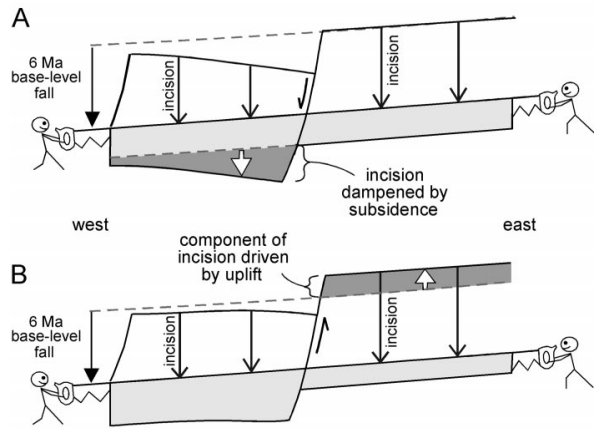

Figure 3. Illustration of influence of faulting on river incision. Base-level fall driving most regional incision (black arrow on left) ultimately was caused by drainage integration off west edge of Colorado Plateau. Using river profile (saw) as reference for two scenarios, differential incision where fault-slip rates are less than regional incision geometrically implies either (A) hanging-wall subsidence reducing incision west of fault, or (B) footwall rock uplift driving component of, but not all, upstream incision. Considering regional tectonic and structural context, Grand Canyon likely represents situation A. Data are not yet available to determine if incision rates vary west of Toroweap fault due to listric rotation as implied here.

upper Gray Ledge and Massive Diabase flows (dated as $97 \pm 32$ and $296 \pm 57 \mathrm{ka}$, respectively) where the Hurricane fault crosses the Colorado River, though placement of the fault is debated (Fenton et al., 2001). It follows that Quaternary slip at the river may be mostly along the Toroweap fault.

\section{DISCUSSION}

Our data suggest that the Toroweap fault's slip rate $(94 \mathrm{~m} / \mathrm{m} . \mathrm{y}$.) is approximately equal to the difference between upstream $(\sim 140 \mathrm{~m} /$ m.y.) and downstream ( $<72-92 \mathrm{~m} / \mathrm{m} . \mathrm{y}$.) incision rates, considering that our range of values for Granite Park is a maximum estimate. Subsidence in the hanging wall of the Toroweap fault may therefore account for differential incision by effectively dampening incision rates west of the fault zone (Fig. 3A). We also speculate that the fault may be listric with subsidence maximized at the fault and decreasing into the footwall block toward Granite Park, and thus decreasing subsidence may be matched by increasing river incision at any given locality west of the fault.

The relation of active tectonics to stream incision is a fundamental issue in geomorphology, and our hypothesis that fault slip reduces downstream incision is distinct from the idea that faulting drives upstream incision in this setting (cf. Hamblin et al., 1981; Fenton et al., 2001). Certainly one way of driving incision is through active rock uplift, the effective base-level fall being transferred upstream through knickpoint migration, as controlled by hydrologic and substrate properties (e.g., Gilbert, 1877; Leopold and Bull, 1979; Gardner, 
1983; Merritts et al., 1994; Weissel and Seidl, 1998). However, other mechanisms also influence local base level, including stream capture, climate change, and drops in sea level, and incision can proceed in landscapes well after tectonic uplift has ceased (Hack, 1960; Pazzaglia and Brandon, 1996; Blum and Tornqvist, 2000). Although there is local faulting in the Grand Canyon, mechanisms other than active tectonics have lowered effective base level and driven a large fraction of stream incision, i.e., surface drainage integration off the Grand Wash escarpment at the southwest edge of the Colorado Plateau. This view is consistent with the Toroweap and Hurricane faults being an expression of Basin and Range crustal thinning and subsidence that migrated into an already elevated Colorado Plateau. In addition, our calculations indicate that upstream incision by the Colorado River has been faster than rates of local faultingknickpoint generation. This is also evident in that there has been incision (albeit slower) downstream of the fault zone rather than aggradation, which would be expected if faulting was faster than regional incision (cf. Hamblin et al., 1981). Given the context of (1) regional incision driven by other factors such as drainage development; (2) faulting that is slower than regional incision; and (3) tectonics consistent with mostly subsidence of the hanging wall relative to the geoid, we conclude that local faulting does not drive upstream incision, but rather locally reduces incision in the Grand Canyon (Fig. 3A). If faulting in this region was instead an expression of rock uplift in the footwall block, and conditions 1 and 2 were still true, local faulting would drive some component of upstream incision, but not all of it (Fig. 3B).

Incision along the Colorado River at $\sim 140$ $\mathrm{m} / \mathrm{m}$.y., if constant since the proposed initiation of incision at $6 \mathrm{Ma}$, could carve less than half of the $\sim 1800$-m-deep gorge of the eastern Grand Canyon. This suggests that (1) rates have slowed through time, consistent with an attenuating wave of incision initiated by a relatively sudden, large base-level fall; and/or (2) that some canyon cutting, at least in the eastern Grand Canyon, happened prior to the Colorado River taking its full present path at 6 Ma and creating the Grand Canyon we see today.

\section{ACKNOWLEDGMENTS}

Research has been supported by the Geological Society of America's Gladys Cole Memorial Award to Pederson, National Science Foundation (NSF) grant EAR-9706541 to Karlstrom, and NSF grant EAR-0107065 to Pederson and Karlstrom. We thank Grand Canyon National Park for providing research access, Greg Hancock and numerous other colleagues for discussions and improvements to the manu- script, Timothy Randle of the U.S. Bureau of Reclamation for river-depth data, and Mark Gonzales for survey help.

\section{REFERENCES CITED}

Birdseye, C.H., 1924, Plan and profile of Colorado Rive from Lees Ferry, Arizona to Black Canyon, ArizonaNevada, and Virgin River, Nevada: U.S. Geological Survey, 21 sheets.

Blackwelder, E., 1934, Origin of the Colorado River: Geological Society of America Bulletin, v. 45, p. $551-565$.

Blum, M.D., and Tornqvist, T.E., 2000, Fluvial responses to climate and sea-level change; a review and look forward: Sedimentology, v. 47, p. 2-48.

Brumbaugh, D.S., 1987, A tectonic boundary for the southern Colorado Plateau: Tectonophysics, v. 136, p. $125-136$

Dalrymple, G.B., and Hamblin, W.K., 1998, K-Ar ages of Pleistocene lava dams in the Grand Canyon in Arizona: National Academy of Sciences Proceedings, v. 95 , p. $9744-9749$.

Edwards, R.L., Chen, J.H., and Wasserburg, G.J., 1987, ${ }^{238} \mathrm{U}-{ }^{234} \mathrm{U}-{ }^{230} \mathrm{Th}-{ }^{232} \mathrm{Th}$ systematics and the precise measurement of time over the past 500000 years: Earth and Planetary Science Letters, v. 81, p. $175-192$.

Faulds, J.E., Schreiber, B.C., Reynolds, S.J., Gonzalez, L.A., and Okaya, D., 1997, Origin and paleogeography of an immense, nonmarine Miocene salt deposit in the Basin and Range (western USA): Journal of Geology, v. 105, p. 19-36.

Faulds, J.E., Price, L.M., and Wallace, M.A., 2002, PreColorado River paleogeography and extension along the Colorado Plateau-Basin and Range boundary, northwest Arizona, in Young, R.A., and Spamer, E.E., eds., The Colorado River: Origin and evolution: Grand Canyon, Arizona, Grand Canyon Association Monograph 12 (in press)

Fenton, C.R., Webb, R.H., Pearthree, P.A., Cerling, T.E., and Poreda, R.J., 2001, Displacement rates on the Toroweap and Hurricane faults: Implications for Quaternary downcutting in the Grand Canyon, Arizona: Geology, v. 29, p. 1035-1038.

Gardner, T.W., 1983, Experimental study of knickpoint and longitudinal profile evolution in cohesive, homogeneous material: Geological Society of America Bulletin, v. 94 , p. 664-672

Gardner, T.W., Jorgensen, D.W., Shuman, C., and Lemieux, C.R., 1987, Geomorphic and tectonic process rates: Effects of measured time interval: Geology, v. 15 p. 259-261.

Gilbert, G.K., 1877, Geology of the Henry Mountains (Utah): U.S. Geographical and Geological Survey of the Rocky Mountains Region: Washington, D.C., U.S. Government Printing Office, $170 \mathrm{p}$.

Hack, J.T., 1960, Interpretation of the erosional topography in humid temperate regions: American Journal of Science, v. 258-A, p. 80-97.

Hamblin, W.K., Damon, P.E., and Bull, W.B., 1981, Estimates of vertical crustal strain rates along the western margins of the Colorado Plateau: Geology, v. 9, p. 293-298.

Hamblin, W.K., 1994, Late Cenozoic lava dams in the western Grand Canyon: Geological Society of America Memoir 183, 139 p.

Jackson, G., 1990, Tectonic geomorphology of the Toroweap fault, western Grand Canyon, Arizona: Implications for transgression of faulting on the Colorado Plateau: Arizona Geological Survey Open-File Report $90-4,67 \mathrm{p}$

Leopold, L.B., and Bull, W.B., 1979, Base level, aggradation, and grade: American Philosophical Society Proceedings, v. 123, p. 168-202.

Longwell, C.R., 1946, How old is the Colorado River? American Journal of Science, v. 244, p. 817-835.

Lucchitta, I., 1966, Cenozoic geology of the upper Lake Mead area adjacent to the Grand Wash Cliffs, Arizona [Ph.D. thesis]: State College, Pennsylvania State University, $218 \mathrm{p}$

Lucchitta, I., 1972, Early history of the Colorado River in the basin and range province: Geological Society of America Bulletin, v. 83, p. 1933-1947.
Lucchitta, I., Curtis, G.H., Davis, M.E., Davis, S.W., and Turrin, B., 2000, Cyclic aggradation and downcutting, fluvial response to volcanic activity, and calibration of soil-carbonate stages in western Grand Canyon: Quaternary Research, v. 53, p. 23-33.

Lucchitta, I., Curtis, G.H., Davis, M.E., Davis, S.W., and Turrin, B., 2002, Rates of downcutting of the Colorado River in the Grand Canyon region, in Young, R.A., and Spamer, E.E., eds., The Colorado River: Origin and evolution: Grand Canyon, Arizona, Grand Canyon Association Monograph 12 (in press).

Machette, M.N., and Rosholt, J.N., 1991, Quaternary geology of the Grand Canyon, in Morrison, R.B., ed, Quaternary nonglacial geology: Conterminous U.S. Boulder, Colorado, Geological Society of America, Geology of North America, v. K-2, p. 397-401.

Merritts, D.J., Vincent, K.R., and Wohl, E.E., 1994, Long river profiles, tectonism, and eustasy: A guide to interpreting fluvial terraces: Journal of Geophysical Research, v. 99, no. B7, p. 14 031-14 050.

Mills, H.H., 2000, Apparent increasing rates of stream incision in the eastern United States during the late Cenozoic: Geology, v. 28, p. 955-957.

Pazzaglia, F.J., and Brandon, M.T., 1996, Macrogeomorphic evolution of the post-Triassic Appalachian Mountain determined by deconvolution of the offshore basin sedimentary record: Basin Research, v. 8, p. 255-278.

Potochnik, A.R., and Faulds, J.E., 1998, A tale of two rivers: Tertiary structural inversion and drainage reversal across the southern boundary of the Colorado Plateau, in Duebendorfer, E.M., ed., Geologic excursions in northern and central Arizona (GSA Rocky Mountain Section field trip guidebook): Flagstaff, Northern Arizona University, p. 149-174

Spencer, J.E., Peters, L., McIntosh, W.C., and Patchett, P.J. 2002, $\mathrm{Ar}^{40} / \mathrm{Ar}^{39}$ geochronology of the Hualapai Limestone and Bouse Formation and implications for the age of the lower Colorado River, in Young, R.A. and Spamer, E.E., eds., The Colorado River: Origin and evolution: Grand Canyon, Arizona, Grand Canyon Association Monograph 12 (in press).

Stenner, H.D., Lund, W.R., Pearthree, P.A., and Everitt, B.L., 1999, Paleoseismologic investigations of the Hurricane fault in northwestern Arizona and southwestern Utah: Arizona Geological Survey Open-File Report 99-8, $136 \mathrm{p}$

Weissel, J.K., and Seidl, M.A., 1998, Inland propagation of erosional escarpments and river profile evolution across the southeast Australian passive continental margin, in Tinkler, K.J., and Wohl, E.E., eds., Rivers over rock: Fluvial processes in bedrock channels: Washington, D.C., American Geophysical Union, p. 189-206.

Wenrich, K.J., Billingsley, G.G., and Huntoon, P.W., 1997, Breccia-pipe and geologic map of the northeastern part of the Hualapai Indian reservation and vicinity, Arizona: U.S. Geological Survey Map I-2440, scale $1: 48000$

Wilson, R.P., 1986, Sonar patterns of Colorado River bed, Grand Canyon, in Glysson, G.D., ed., Proceedings of the Fourth Federal Interagency Sedimentation Conference (two volumes): Tucson, Interagency Advisory Commission on Water Data, Subcommittee on Sedimentation, p. 5.133-5.142.

Wong, I.G., and Humphreys, J.R., 1989, Contemporary seismicity, faulting, and the state of stress in the Colorado Plateau: Geological Society of America Bulletin, v. 101, p. 1127-1146.

Young, R.A., and Brennan, W.J., 1974, Peach Springs Tuff: Its bearing on structural evolution of the Colorado Plateau and development of Cenozoic drainage in Mohave County, Arizona: Geological Society of America Bulletin, v. 85, p. 83-90.

Young, R.A., and McKee, E.H., 1978, Early and middle Cenozoic drainage and erosion in west-central Arizona: Geological Society of America Bulletin, v. 89, p. $1745-1750$.

Manuscript received November 23, 2001

Revised manuscript received April 23, 2002

Manuscript accepted April 26, 2002

Printed in USA 